\title{
DESAIN DAN APLIKASI SISTEM GERAK PARALEL, H FRAME, PEMOSISIAN GERAK SUMBU XY PADA PRINTER TIGA DIMENSI
}

\author{
Didi Widya Utama ${ }^{1}$, Steven Darmawan ${ }^{1}$, Renaldi Putra Widjaya ${ }^{1}$ \\ ${ }^{1}$ Lab. Mekatronika Jurusan Teknik Mesin, Universitas Tarumanagara Jakarta \\ didiu@ft.untar.ac.id
}

\begin{abstract}
ABSTRAK
Aplikasi mesin rapid prototipe dengan metode manufaktur aditif dewasa ini berkembang secara pesat, teknologi metode manufaktur aditif salah satunya adalah Fused Deposition Modeling dimana sebuah nosel yang melelehkan filamen bergerak pada sebuah bidang XY sesuai pola yang diprogram dan terus berlanjut selapis demi selapis dan ahirnya membentuk bentuk benda 3 dimensi sesuai yang dikehendaki. Salah satu faktor keberhasilan dalam mesin ini terletak pada sistem gerak sumbunya terutama gerakan sumbu arah X dan arah $Y$. Paralel XY adalah salah satu sistem gerak pada $3 D$ printer yang merupakan sebuah mekanisme penggerak dengan sistem sabuk bergerigi yang disusun dengan konfigurasi $H$ dan sistem gerak ini menentukan tingkat, akurasi dari hasil cetak yang biasanya disebut resolusi. Resolusi maksimum yang sistem gerak XY yang dikehendaki adalah empat puluh mikrometer. Untuk mencapai resolusi tersebut pada prancangan ini, dilakukan pemodelan dan simulasi pembebanan menggunakan software Autodesk Inventor Professional 2017 untuk menghindari terjadinya defleksi atau deformasi. Dari hasil simulasi pembebanan, konstruksi menunjukan komponen tidak mengalami defleksi atau deformasi dengan nilai lebih dari empat puluh mikrometer dan penggabungan konstruksi ini dengan sistem gerak XY ini dapat menghasilkan hasil cetak yang memiliki resolusi maksimum hingga empat puluh mikrometer.
\end{abstract}

Kata kunci: Paralel XY, Fused Deposistion Modeling, resolusi

\section{PENDAHULUAN}

Sistem manufaktur aditif adalah merupakan metode manufaktur yang memiliki kelebihan dimana metode ini lebih efisien dalam penggunaan material, efektif dari segi waktu pengerjaan dan mengkonsumsi energi yang relatif lebih rendah. Sistem Fused Deposition Modeling (FDM) merupakan metode pada mesin printer 3Dimensi yang saat ini banyak digunakan karena memiliki tingkat biaya yang rendah dan ekonomis dalam penyediaan peralatannya (Vinod G. Surange, 2016). Pada mesin printer 3Dimensi bertipe FDM, menggunakan sistem gerak katesian $\mathrm{X}$ dan $\mathrm{Y}$ pada setiap lapisan dengan menggerakan nosel yang mengeluarkan material filament yang meleleh pada posisi yang dikehendaki sehingga membentuk lapisan berupa geometri tertentu. Gerakan tiap lapisan ini diulang sesuai kebutuhan dari bentuk geometeri yang dikehendaki sehingga seluruh lapisan geometri tersebut membentuk model 3dimensi sesuai model dari CAD data. Penerapan sistem gerak kartesian ini banyak diadopsi beberapa sistem gerak seperti sistem gerak dengan menggunakan sabuk sinkron, lead screw, ball screw, bahkan menggunakan sistem pneumatik. (Chua \& Kah Fai Leong, 2003) 


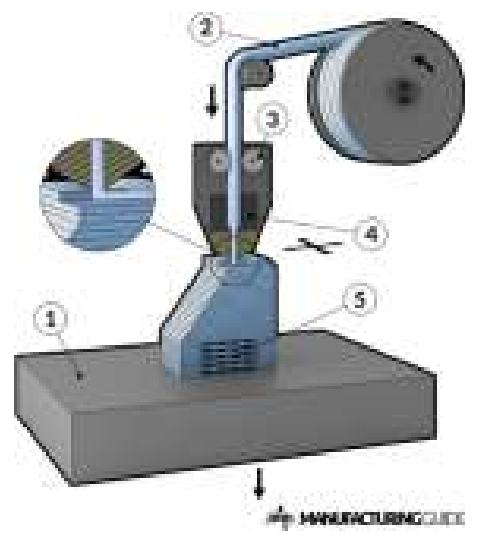

Gambar 1. Metode fused deposition modeling. (Hans Bergmark,Jessica Bergmark,et al, 2015)

Sebelumnya sistem gerak kartesian XY banyak diaplikasikan pada industri dimana fungsinya adalah untuk melakukan pemosisian terhadap suatu alat dengan cepat dan akurat. Terdapat banyak sistem gerak yang telah diterapkan antara lain sistem dengan menggunakan pengarah linier dengan pergerakan yang digerakkan oleh lead screw/ball screw, sabuk tersinkron, sistem pneumatic dan hidrolik dan lain sebagainya. (K. Itoh, 2004) sistem gerak yang demikian jika diterapkan pada mesin printer 3Dimensi maka akan mengakibatkan pada pemborosan ruangan, kurang praktis dan kurang ekonomis. Berlatar belakang hal ini maka dikembangkan sistem gerak yang ringkas, mudah diterapkan namun masih dapat mengakomodir kebutuhan sistem gerak pada mesin printer 3Dimensi dalam hal akurasi, kecepatan dan beban yang dipindahkan. (Joshua M. Pearce, 2010)

Sistem gerak parallel XY menggunakan konfigurasi H pada sistem belt sinkron dimana sistem ini menggunakan belt sinkron tunggal untuk menggerakkan nosel pada mesin printer 3Dimensi pada suatu sumbu gerak X dan Y. (Klaus Sollmann, 2010) sistem ini dapat dilihat pada gambar dibawah ini:

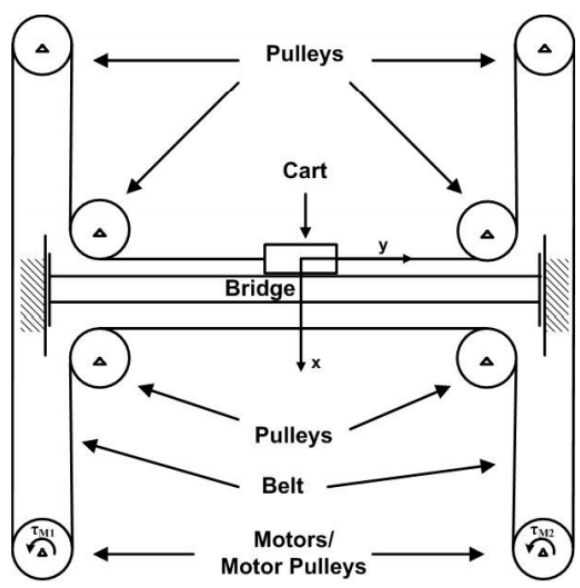

Gambar 2. Konfigurasi sistem gerak rangka $H$

Pada penerapan desain di penelitian ini menggunakan sistem gerak parallel XY dengan menggunakan 2 buah sabuk yang mengontrol secara simultan gerakan $\mathrm{X}$ dan $\mathrm{Y}$, hal ini sedikit berbeda dengan sistem gerak pada konfigurasi $\mathrm{H}$ yang menggunakan 1 buah sabuk. (Klaus Sollmann, 2010).

Dalam makalah ini akan dibahas desain dan aplikai sistem gerak kartesian dengan menerapakan parallel XY dengan frame $\mathrm{H}$ untuk memposisikan nosel pada mesin printer 3Dimensi, selain itu 
pengujian akurasi gerak sumbu $\mathrm{X}$ dan $\mathrm{Y}$ dilakukan dengan metode eksperimental, simulasi Finite Element Analysis (FEA) dilakukan pada komponen-komponen yang fungsional sehingga dapat menghasilkan sistem gerak yang memiliki akurasi tinggi.

\section{METODOLOGI PERANCANGAN}

Metode yang digunakan dalam perancangan konstruksi pada 3D printer dengan sistem gerak ini adalah metode analitis Finite Element untuk menganalisa kekuatan dan difleksi dari hasil desain menggunakan software yang sebelumnya setiap komponen dimodelkan dalam bentuk 3Dimensi dimana keuntungan metode ini adalah didapatkan model yang akurat dan dapat mudah dilakukan analisa spasial antar komponen dengan baik, serta data CAD dari model ini langsung dapat di lakukan analisis FEA. Setelah analisis dilakukan dan hasilnya dinyatakan aman, maka model CAD tersebut langsung dapat dijadikan referensi data untuk dilakukan manufaktur tanpa terjadi distrosi data akibat dari konversi tersebut. (Utama, 2015)

Penelitian diawali dengan membatasi permasalahan pada topik yang akan dibahas, dilanjutkan dengan mengumpulkan informasi yang dibutuhkan tentang sistem gerak paralel XY. Pemodelan tiga dimensi dilakukan untuk kemudian dianalisa menggunakan software Autodesk Inventor Professional terhadap kekuatan dan kekakuan strukturnya dengan menggunakan simulasi pemberian pembebanan statis sesuai dengan perhitungan. Simulasi pengujian defleksi dilakukan terhadap penyangga utama yang menumpu sistem gerak pada kerangka utama dan pada bagian penumpu hasil cetak dari 3D printer kedua komponen ini merupakan bagian penting pada system gerak yang menunjang akurasi dari hasi cetak, apabila pada analisa dan hasil simulasi rancangan tidak mengalami defleksi atau deformasi di luar batas yang telah ditentukan, maka rancangan dikatakan aman dan proses dilanjutkan dengan pembuatan komponen. Namun jika hasil dari analisis terindikasi defleksi yang melebihi batas yang ditentukan yakni $>40$ mikrometer maka rancangan dilakukan desain ulang dengan cara memperkuat bagian yang terlemah.
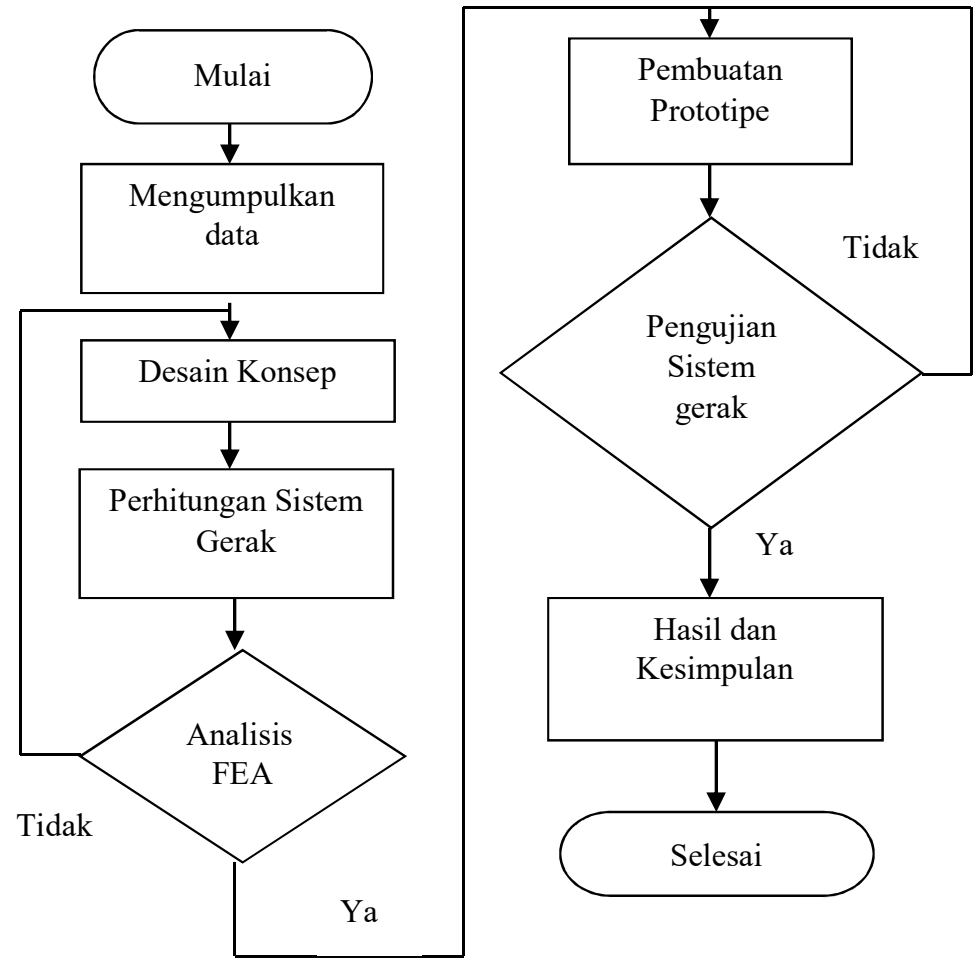

Gambar 3. Diagram alir perancangan 


\section{HASIL DAN PEMBAHASAN}

\section{Desain sistem gerak parallel $\mathrm{XY}$}

Sistem gerak parallel XY merupakan sebuah rangkaian parallel yang terdiri dari dua pasang batang yang disusun secara horizontal dan vertikal dimana kedua pasang batang tersebut harus tegak lurus satu sama lain. Kedua pasang batang tersebut dipasang bantalan luncur sehingga keduanya dapat menghasilkan gerakan vertikal maupun horizontal secara individu maupun bersamaan. Untuk menghasilkan gerakan yang terkoordinasi maka mekanisme system gerak tersebut perlu dipasang penggerak yang dapat mengakomodir gerakan yang terkontrol baik jarak pergerakan, arah gerakan, dan kecepatan gerak, untuk itu system mekanisme dihubungkan dengan menggunakan sabuk sinkron sehingga tidak terjadi slip pada sabuk. Dua buah motor stepper tipe NEMA 17 dengan stepping angle sebesar 1,8 $8^{\circ}$ digunakan untuk menggerakkan kedua belt yang mengontrol gerakan arah sumbu X dan Y, konsep system gerak ini digambarkan pada gambar 4 .

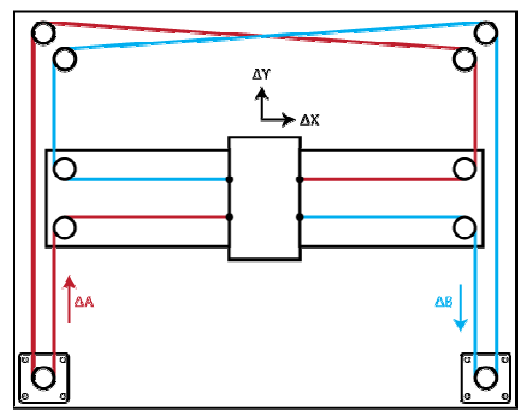

Gambar 4. Konfigurasi sistem gerak parallel XY (Moyer, 2012)

Gerakan sumbu dapat dikontrol dengan mengatur sudut putar pada motor stepper, memutar kedua motor stepper pada arah putar yang sama akan menghasilkan gerakan sumbu horizontal dan memutar motor stepper dengan arah berlawanan maka akan menghasilkan gerakan vertikal. Besaran translasi sumbu gerak ditujukkan pada persamaan dibawah ini:

$$
\begin{gathered}
\Delta \mathrm{X}=1 / 2(\Delta \mathrm{A}+\Delta \mathrm{B}), \Delta \mathrm{Y}=1 / 2(\Delta \mathrm{A}-\Delta \mathrm{B}) \\
\Delta \mathrm{A}=\Delta \mathrm{X}+\Delta \mathrm{Y}, \Delta \mathrm{B}=\Delta \mathrm{X}-\Delta \mathrm{Y}
\end{gathered}
$$

Desain dari sistem gerak tersebut dilakukan dengan menggunakan software Autodesk Inventor 2017 hasil dari desain ditunjukkan pada gambar 5.

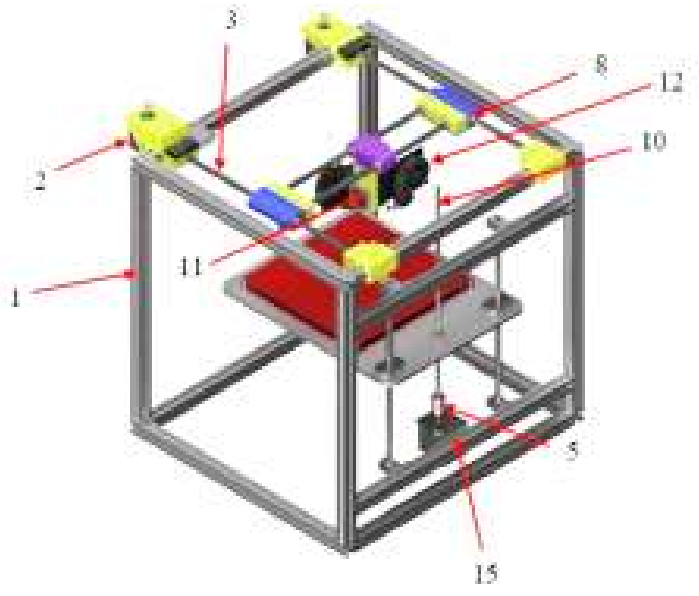

Keterangan:

1. Rangka

2. Motor Stepper

3. Batang luncur

5. Kopling

8. Bantalan Luncur

10. Lead Screw

11. Nosel

12. Fan

Gambar 5. Desain 3 dimensi prototipe mesin printer 3D 


\section{Perhitungan pembebanan}

Perhitungan tegangan maksimal berdasarkan massa pembebanan dengan perbandingan tegangan maksimal izin dari bahan yaitu stainless steel 304.

Jika diketahui: $\mathrm{m}=\mathrm{m} \_\mathrm{s}=1 \mathrm{~kg}, \mathrm{l}=350 \mathrm{~mm}, \mathrm{~d}=10 \mathrm{~mm}, \sigma=215 \mathrm{MPa}$ (yield strength)

maka:

Jika diketahui: $\mathrm{m}=\mathrm{m}_{\mathrm{s}}=1 \mathrm{~kg}, 1=350 \mathrm{~mm}, \mathrm{~d}=10 \mathrm{~mm}, \sigma=215 \mathrm{MPa}$ (yield strength)

maka:

Gaya pembebanan dalam Newton:

$\mathrm{F}_{\mathrm{w}}=\mathrm{m} \times \mathrm{g}$

$\mathrm{F}_{\mathrm{W}}=1 \mathrm{~kg} \times 9,81 \mathrm{~m} / \mathrm{s}^{2}$

$\mathrm{F}_{\mathrm{w}}=9,81 \mathrm{~N}$

Perhitungan percepatan:

$\mathrm{a}=\frac{\Delta \mathrm{v}}{\Delta \mathrm{t}}$

$\mathrm{a}=\frac{0,0156-0}{16-0}$

$\mathrm{a}=9,75 \times 10^{-4} \mathrm{~m} / \mathrm{s}^{2}$

(percepatan diabaikan karena nilainya sangat kecil)

Perhitungan percepatan gaya dari slider:

$\mathrm{F}_{\mathrm{a}}=\mathrm{m}_{\mathrm{s}} \cdot \mathrm{a}$

$\mathrm{F}_{\mathrm{a}}=1 \mathrm{~kg} \cdot 9,75 \times 10^{-4} \mathrm{~m} / \mathrm{s}^{2}$

$\mathrm{F}_{\mathrm{a}}=9,75 \times 10^{-4} \mathrm{~N}$

(percepatan gaya diabaikan karena nilainya sangat kecil)

Perhitungan gaya gesek dari linier ball bearing:

$\mathrm{F}_{\mathrm{f}}=\mu_{\mathrm{r}} \cdot \mathrm{m}_{\mathrm{s}} \cdot \mathrm{g} \cdot \cos \beta+\mathrm{F}_{\mathrm{fi}}$

$\mathrm{F}_{\mathrm{f}}=0,005 \cdot 1 \mathrm{~kg} \cdot 9,81 \cdot \cos 0^{\circ}+3,5 \mathrm{~N}$

$\mathrm{F}_{\mathrm{f}}=3,55 \mathrm{~N}$

Perhitungan gaya pembebanan total pada shaft:

$\mathrm{F}_{\text {total }}=\mathrm{F}_{\mathrm{w}}+\mathrm{F}_{\mathrm{f}}$

$F_{\text {total }}=9,81 \mathrm{~N}+3,55 \mathrm{~N}$

$\mathrm{F}_{\text {total }}=13,36 \mathrm{~N}$

Reaksi tumpuan pada shaft:

$\mathrm{R}=\frac{1}{2} \times \mathrm{F}_{\mathrm{w}}$

$\mathrm{R}=\frac{1}{2} \times 13,36 \mathrm{~N}$

$\mathrm{R}=6,68 \mathrm{~N}$

Momentum maksimal pada shaft:

$\mathrm{M}_{\max }=\mathrm{R} \times \mathrm{L}$

$\mathrm{M}_{\max }=6,68 \mathrm{~N} \times 175 \mathrm{~mm}$

$\mathrm{M}_{\max }=1169 \mathrm{Nmm}$

Momen Inersia shaft:

$\mathrm{I}=\frac{\pi}{64} \times \mathrm{d}^{4}$

$\mathrm{I}=\frac{3.14}{64} \times 10^{4}$

$\mathrm{I}=490,63 \mathrm{~mm}^{4}$ 
Tegangan maksimal aktual pada shaft:

$\begin{aligned} \sigma_{\text {aktual }} & =\frac{1169 \times \frac{10}{2}}{490,63} \\ \sigma_{\text {aktual }} & =11,91 \mathrm{MPa}\end{aligned}$

Safety Factor yang digunakan adalah 1,5.

Maka tegangan maksimal pada shaft:

$\sigma_{\max }=11,91 \mathrm{MPa} \times 1,5$

$\sigma_{\max }=17,87 \mathrm{MPa}$

Struktur rangka memenuhi syarat aman berdasarkan persamaan berikut:

$$
\sigma>\sigma_{\max }
$$

$215 \mathrm{MPa}>17,87 \mathrm{MPa}$

Tegangan efektif yang terjadi pada timing belt yang terdiri dari:

1. gaya dari luar sistem;

2. percepatan gaya dari slider;

3. gaya gesek dari linier ball bearing;

4. gaya pembebanan berdasarkan kemiringan;

5. gaya inersia belt dari percepatan;

6. gaya inersia puli dari percepatan;

Perhitungan tegangan efektif pada sistem timing belt:

$\mathrm{T}_{\mathrm{e}}=\mathrm{F}_{\mathrm{a}}+\mathrm{F}_{\mathrm{f}}+\mathrm{F}_{\mathrm{w}}+\mathrm{F}_{\mathrm{g}}+\mathrm{F}_{\mathrm{ab}}+\mathrm{F}_{\mathrm{ai}}$

$\mathrm{T}_{\mathrm{e}}=0+3,55 \mathrm{~N}+9,81+0+0+0$

$\mathrm{T}_{\mathrm{e}}=13,36 \mathrm{~N}$

\section{Analisa finite element}

Analisa menggunakan metode ini dilakukan pada bagian utama system gerak yakni komponen motor stepper mounting dan pada mounting roda pully. Tujuan dari analisis ini untuk mendapatkan desain yang aman dengan defleksi $<40$ mikrometer. Boundary condition disesuaikan pada tumpuan komponen dan pembebanan berasal dari beban tegangan sabuk yakni sebesar 13,36 N. Kedua komponen ini akan dilakukan manufaktur dengan menggunakan plastic ABS melalui metode aditif manufaktur, pada simulasi FEA material yang digunakan adalah ABS plastic dengan yield point sebesar 20 MPA.

Berikut hasil simulasi finite element dari kedua komponen dapat dilihat pada
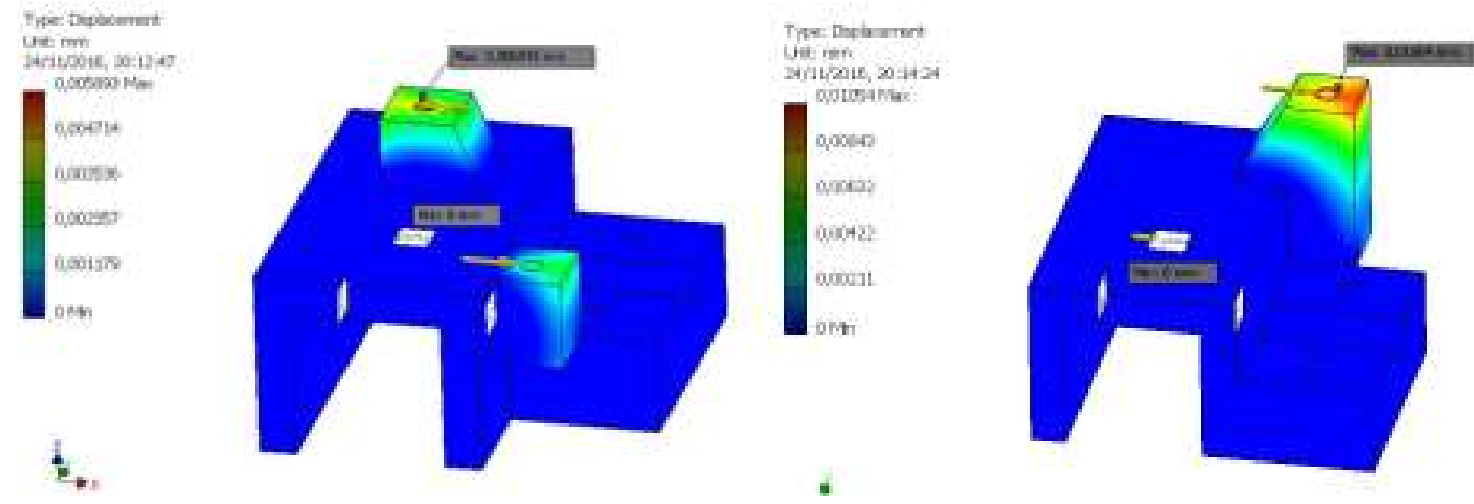

Gambar 6. Hasil analisa FEA pada mounting roda pully. 
Displacement maksimum pada mounting roda pulley kiri sebesar $0,005893 \mathrm{~mm}=5,893$ mikrometer, sedangkan Displacement maksimum pada mounting roda pulley kanan sebesar $0,01054 \mathrm{~mm}=10,54$ mikrometer, lokasi dari area ini terlihat pada gambar diatas bagian yang berwarna hijau-merah.
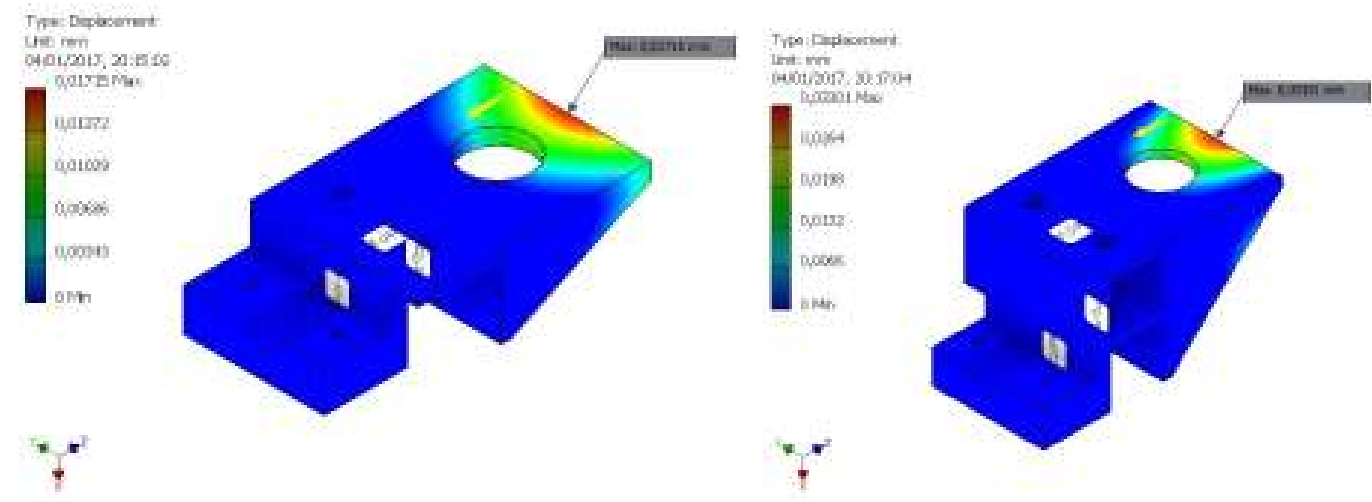

Gambar 7. Hasil analisa FEA pada mounting motor stepper.

Displacement maksimum pada mounting motor stepper kiri sebesar $0,01715 \mathrm{~mm}=17,15$ mikrometer, sedangakan displacement maksimum pada mounting motor stepper kanan sebesar $0,03301 \mathrm{~mm}=33,01$ mikrometer.

Bagian penyangga pada mesin 3D printer merupakan bagian yang dapat mempengaruhi akurasi terhadap hasil cetak terutama pada sumbu $\mathrm{Z}$ dimana penyangga ini tidak diperbolehkan terjadi defleksi melebihi resolusi minimal dari mesin 3Dprinter yakni sebesar $<100$ mikrometer.

Pada saat mesin mencetak benda maka dengan dimensi maksimal area cetak sebesar $210 \mathrm{~mm} \mathrm{x}$ $210 \mathrm{~mm}$ dan $210 \mathrm{~mm}$ dengan menggunakan bahan ABS plastik, hasil cetak ini di hasilkan dari simulasi menggunakan perangkat lunak 3D Printer yakni Repetier host, dimana hari hasil analisa dapat diperoleh secara akurat kebutuhan filament plastic tersebut yakni sebesar $836.905 \mathrm{~mm}$ dimana dengan perhitungan terhadap volume filament dikalikan dengan massa jenis ABS plastic sebesar 1,05 gram $/ \mathrm{cm}^{3}$ maka diperoleh beban hasil cetak adalah sebesar 21,12 N. Beban ini dijadikan boundary condition pada simulasi FEA dan hasil yang didapat dari simulasi pada rangka penyangga utama yang terbuat dari aluminimum dapat dilihat pada gambar 8 .

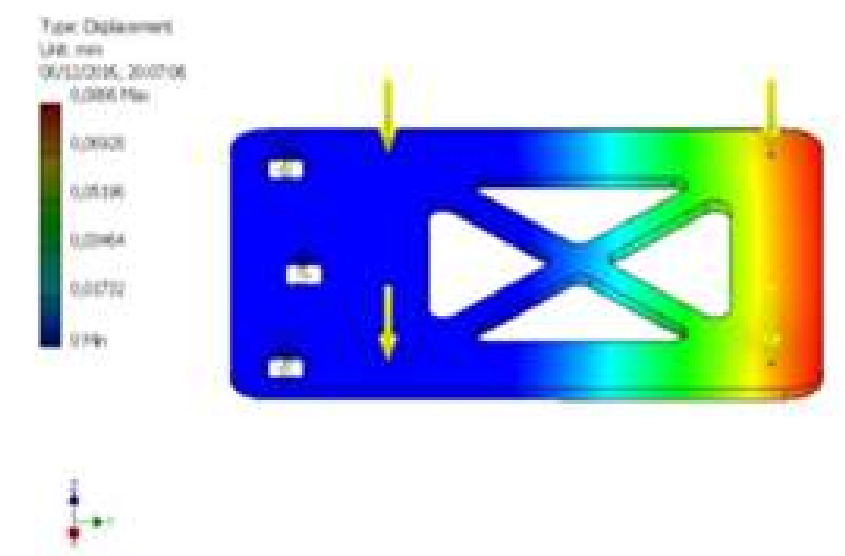

Gambar 8. Hasil analisa FEA pada komponen penyangga utama. 
Dari hasil simulasi diatas diperoleh displacement maksimum adalah sebesar 0,0866 $\mathrm{mm}=86,6$ mikrometer, maka dapat disimpulkan bahwa rancangan aman. Namun demikian penyangga utama yang terbuat dari aluminium tebal $5 \mathrm{~mm}$ dengan berat sebesar $0,893 \mathrm{Kg}$ belum diperhitungakan dalam pembebanan secara keseluruhan terhadap struktur utama.

\section{Prototipe fisik dan pengujian sistem gerak parallel XY.}

Setelah tahap desain dan analisis selesai dilakukan dan rancangan dinyatakan aman, maka tahap selanjutnya adalah melakukan proses pembuatan prototype fisik. Setiap komponen diperioritaskan dalam rancangan adalah kemudahan didapat dipasaran seperti rangka, bantalan, belt, pully, baut pengikat dll, jika terdapat komponen yang harus dibuat secara unik seperti mounting pully dan motor stepper, dan mounting bantalan luncur maka komponen tersebut dibuat dengan menggunakan metode aditif manufacturing dengan mesin printer 3D. Setelah setiap komponen dibuat dan selanjutnya dilakukan perakitan dan pengujian system geraknya. Pengujian ini dilakukan dengan memasang probe berupa pena pada bagian nosel dan sistem digerakkan dengan arah sumbu $\mathrm{X}$ dan $\mathrm{Y}$ masing-masing sumbu digerakkan sejauh $50 \mathrm{~mm}$ sehingga membentuk sudut siku-siku pengujian ini dilakukan sebanyak 10 kali untuk setiap gerakan siku, dimana goresan pena ini digoreskan pada kertas millimeter blok untuk melihat secara visual penyimpangan yang terjadi dan hasil dari goresan gerakan sumbu gerak diukur pada keratas millimeter dan dilihat penyimpangan geraknya.

Berikut gambar 9 adalah prototype yang telah dirakit dan pada gambar 10 adalah hasil pengujian sumbu gerak arah X dan dan Y. Dari gambar 10 terlihat bahwa gerakan sumbu terhadap arah parallel $\mathrm{X}$ maupun $\mathrm{Y}$ tidak terjadi penyimpangan yang berarti, hal ini menunjukkan tidak adanya ketidak sejajaran sumbu pada gerakan arah X maupun arah Y. Selanjutnya terlihat pula pada gambar 10 bahwa ketegak lurusan sumbu juga terlihat tidak terjadi penyimpangan yang berarti, hal ini dapat dikatakan bahwa pemasangan komponen dilakukan secara tegak lurus antara batang horizontal terhadap batang vertikal.

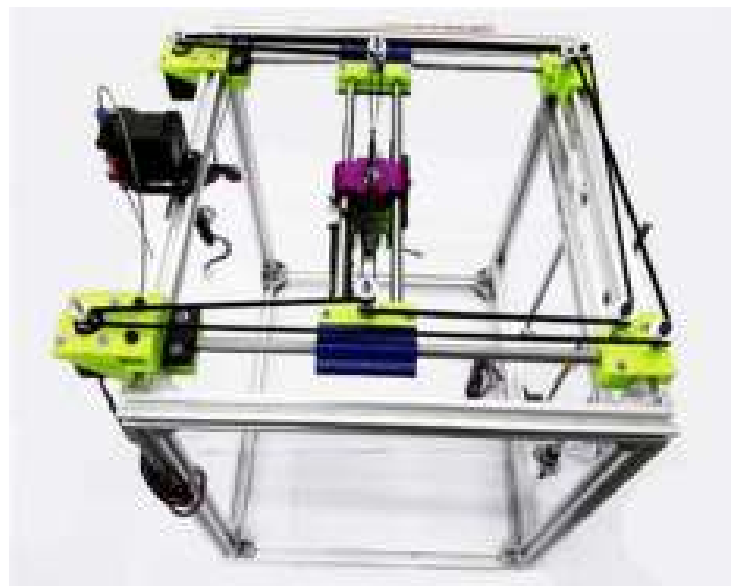

Gambar 9. Prototipe fisik printer 3D dengan parallel XY. 

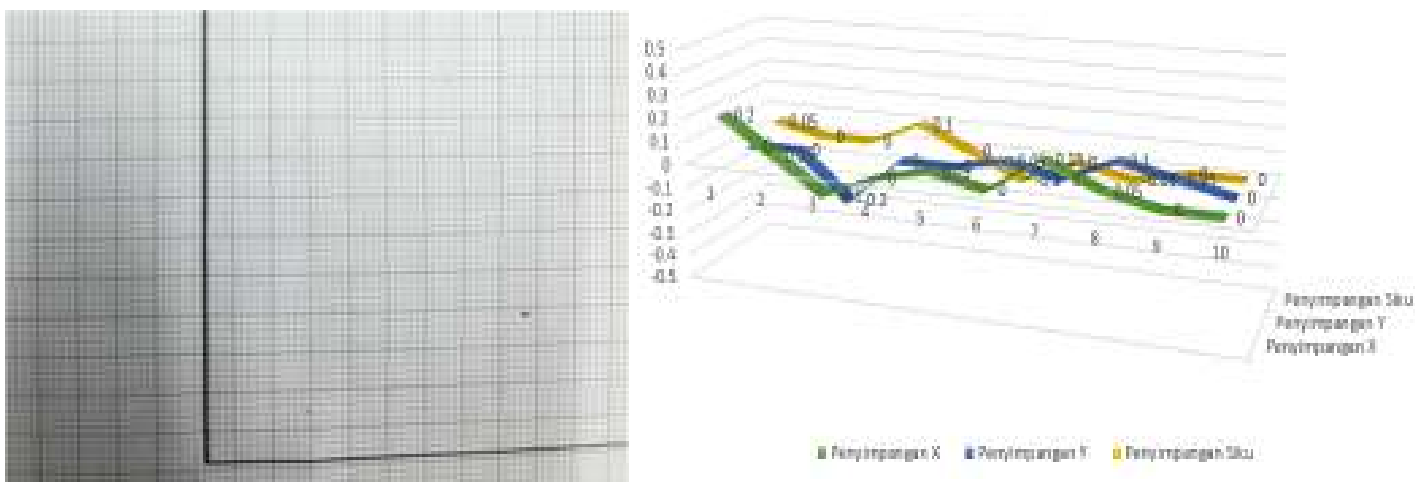

Gambar 10. Hasil pengujian sumbu gerak arah X dan Y.

\section{KESIMPULAN DAN SARAN}

Hasil perancangan yang telah dilakukan dapat disimpulkan bahwa desain berhasil dilakukan sesuai kebutuhan yang ada, analisis FEA menunjukkan bahwa penyimpangan displacement akibat beban pada komponen utama masi dibawah yang ditentukan. Sistem gerak parallel XY yang dirancang dapat berfungsi dengan baik dan melalui hasil pengujian terhadap system gerak, hasilnya adalah parallel dan ketegaklurusan sumbu masih pada batas aman. Prototipe fisik berhasil di rakit dan dapat berfungsi dengan baik dan lancar.

Pada bagian penyangga utama masih memiliki berat yang cukup besar hal ini jika dibandingkan dengan berat hasil cetak hampir mendekati 1:1, maka perlu dilakukan optimasi pada komponen penyangga utama. Selain itu system control pada mesin printer ini belum dibahas maka untuk selanjutnya dapat dibahas dan diuji lebih lanjut pada system control.

\section{Ucapan Terima Kasih (Acknowledgement)}

Penelitian ini dilakukan dengan memperoleh hibah dari Direktorat Penelitian dan Pengabdian kepada Masyarakat (DPPM) Universitas Tarumanagara tahun anggaran 2016/2017, untuk itu peneliti hendak mengucapkan banyak terimakasih atas dukungan dari pihak DPPM Universitas Tarumanagara dan pihak yang telah mendukung penelitian ini.

\section{REFERENSI}

AdrianBowyer. (n.d.). Reprap. (The Replicating Rapid Prototyper) Retrieved 07 10, 2016, from http://reprap.org/wiki/File:RepRap_Component_Structure.svg

Chua, C. K., \& Kah Fai Leong, C. S. (2003). Rapid Prototyping Principles and Applications. Singapore: World Scientific Publish Co, Pte.Ltd.

Evans, B. (2012). Practical 3D Printers The Science and Art of 3D Printing. New York: Springer Science+Business Media New York.

Hans Bergmark,Jessica Bergmark,et al. (2015, November 12). Manufacturing Guide. Retrieved from https://www.manufacturingguide.com/en/fused-deposition-modeling-fdm

Joshua M. Pearce, C. M.-Z. (2010). 3-D Printing of Open Source Appropriate Technologies for Self-Directed Sustainable Development. Journal of Sustainable Development, 17-29. 
K. Itoh, M. I. (2004). Robust fast and persice positioning of ball screw-driven table system on machine stand. Proceedings of the 8th IEEE International Workshop on Advanced Motion Control, (pp. 511-515).

Klaus Sollmann, M. J. (2010). Dynamic Modeling of a Two Axes, Parallel, HFrame. IEEE/ASME Transactions on Mechatronics .

Moyer, I. E. (2012). http://www.corexy.com/theory.html. Retrieved 07 10, 2016, from http://www.corexy.com/theory.html

Utama, D. W. (2015). Finite Element Analisys of Modified In-Wheel Electric Motor For Hybrid Electric Motorcycle. 2nd International Conference on Engineering of Tarumanagara (ICET 2015). Jakarta.

Vinod G. Surange, P. V. (2016). 3D Printing Process Using Fused Deposition Modelling (FDM). International Research Journal of Engineering and Technology (IRJET), (pp. 1403-1406). 